\title{
A FRAMEWORK FOR EVALUATION OF PHARMACEUTICAL INDUSTRY DEVELOPMENT IN DEVELOPING COUNTRIES: EVIDENCE FROM IRAN
}

\author{
HUSSEIN SHABANINEJAD ${ }^{1}$, HESAMODDIN MADANI ${ }^{2}$, ZAHRA AHANI AMINEH ${ }^{3}$, EBRAHIM DOOSTZADEH ${ }^{4 *}$ \\ ${ }^{1}$ Department of Health Services Management, School of Health Management and Information Sciences, Iran University of Medical \\ Sciences, Tehran, Iran. ${ }^{2}$ Department of Technology Management, Science and Research Branch, Islamic Azad University, Tehran, Iran. \\ ${ }^{3}$ Department of Communication Management, Kish Branch, University of Tehran, Tehran, Iran. ${ }^{4}$ Department of Technology Management, \\ Roudehen Branch, Islamic Azad University, Tehran, Iran. Email: doostzadeh@samfar.ir
}

Received: 27 November 2015, Revised and Accepted: 14 April 2016

\section{ABSTRACT}

Objectives: The pharmaceutical market is a complex market due to its complicated supply chain and the extent of government regulations in all aspects of the trade lifecycle of drug development. Considering the importance of pharmaceuticals for society and the relevant trend of globalization, managing pharmaceutical industry effectively and efficiently is vital, particularly in developing countries. The present study determines the factors affecting the development of the Iranian pharmaceutical industry based on pharmaceutical mangers' point of view.

Methods: In this study, we assessed managers' perspective about the internal and external key factors affecting the development of pharmaceutical industry. Finally, their perspective about the solutions for the development of pharmaceutical industry was assessed. Accordingly, a self-designed questionnaire was sent to 65 managers at Tamin Pharmaceutical Investment Company, of which, 51 questionnaires were answered by the managers.

Result: Most managers believed generic scheme reflect negatively on the development of the pharmaceutical industry and that external factors have a great impact on its improvement. They believe that branded generic transition along with supporting regulations, investment in Research and Development, and joint venture with foreign companies will improve the pharmaceutical industry.

Conclusion: To sum up, for improving the pharmaceutical industry in the shortest time possible, improvement of technological capabilities and investment in R\&D should be considered.

Keywords: Pharmaceutical industry, Key factors, Generic scheme.

(C) 2016 The Authors. Published by Innovare Academic Sciences Pvt Ltd. This is an open access article under the CC BY license (http://creativecommons. org/licenses/by/4. 0/) DOI: http://dx.doi.org/10.22159/ajpcr.2016.v9i5.10099

\section{INTRODUCTION}

Pharmaceutical sector has a unique characteristic specified as a highly regulated and Research and Development (R\&D) driven industry. Expenditures on $R \& D$ in this industry, in comparison with other industries, are high [1]. Although most of the products of this sector are global ones, which means costs of R\&D are "global joint costs" [2]. On the other hand, since it is essential for health to ensure a high degree of public health and keep public expenditure under control, the pharmaceutical sector is highly regulated [3-5].

There are two kinds of manufacturing company in the pharmaceutical industry: Originator companies and generic companies. Originator companies are active in research, development, management of the regulatory process for new medicines including clinical trials needed for marketing authorization, manufacturing, marketing, and supply of innovative medicines. Generic companies as a second type of company can enter the market with medicines that are equivalent to the original medicines after patent expiry of the pre-existing original products. Their prices are much lower than those of the originator products [6].

While most health-care systems are trying to confine their expenditures [7], drugs comprise a significant portion of the healthcare budget in developing countries. This helps containing public health budgets and ultimately benefits consumers [6]. Although pharmaceutical expenditure makes up a considerable portion of health expenditure (an average of $24.9 \%$ of total health expenditure is spent on medicines) [8], affordability of medicines for patients is important.

Overview of pharmaceutical industry in Iran

The pharmaceutical market in Iran has its own characteristics and should be assessed to understand the effects of some big changes that are considered as turning points in it. In this section, we provide a chronological history of Iran pharmaceutical markets before Islamic revolution so far and major events that happen to it.

The pharmaceutical industry had been dominated by multinational companies (MNCs) before the Iran Islamic revolution (1979) and few Iranian companies produced generic products in the form of branded generic products or under the license of MNCs [9]. Importing pharmaceutical products were the main source of providing medicine and only a few types of medicines were produced by local companies [10]. While the primary goals of the Islamic revolution were self-sufficiency and non-reliance, these affect policies in the pharmaceutical sector; all pharmaceutical companies dominated by government, MNCs driven out from the country, and the main goals of national drug policy (NDP) turned to the production of essential medicines [11]. On the other hand, the World Health Organization support for conducting generic substitution and acute shortage of medicine due to the war of 1980-1988 was the other factor driving the government into the generic scheme. Local production of pharmaceuticals with the specific idea of "Generic Scheme" gave rise to improve equity of access, as stated in NDP, using determining an essential drugs list, regulated prices, manufacturing and prescribing medicines by the international non-proprietary name [12]. As a result, to increase the availability and affordability of pharmaceuticals, local production of medicines was subsidized by the government. Access to new technology and raw materials became difficult and investments by MNCs drastically decreased in Iran's pharmaceutical sector [13]. The government itself imported pharmaceuticals as finished products, raw materials, and introduction of new pharmaceuticals into the market faced big hurdles later in the 1980s [11,14]. Local production had been supported by the government via the provision of hard currency at a 
subsidized rate and high tariff on imported medicines during 1980$1993[9,15]$.

Local production of pharmaceuticals was encouraged by governments, such as other Middle Eastern countries [17], to improve domestic pharmaceutical manufacturing and reducing dependence on imports and also providing universal access followed via strictly controlling prices of pharmaceutical. Pharmaceutical exports eclipsed by these policies [16] and consequently reduce motives for competition at the local domestic market. Generic medicine development and promotion of local production of medicines are the main characteristics of Iran's NDP, in spite of revision by Ministry of Health (MOH) in 2004 [12]. Table 1 shows the pharmaceutical trends in 6 years. As shown in Table 1, Iran's local pharmaceutical products account for $95 \%$ of the local market in volume terms, whereas in value terms imports encompass more than $50 \%$ of the market [18]. Imported medicines are expensive, and the government encourages companies to produce imported drugs locally [11]. Yet, there is a considerable and incremental demand for imported medicine because local manufacturers are unable to produce high-tech medicines [11]

In this study, we assessed pharmaceutical mangers' attitude about the status of Iran pharmaceutical industries' key factors that are critical in terms of their effects on the pharmaceutical industry development. At the end, we asked their viewpoint about the importance of some policies for developing Iran pharmaceutical industry.

\section{METHODS}

A cross-sectional analytical study has been conducted for this study. Accordingly, a self-generated questionnaire for assessing managers' perspective about the status of key factors on Iran's pharmaceutical industry development was employed. These key factors are identified based on deep literature review [3,20,21] as well as an interview with pharmaceutical experts. These factors were divided into two categories: internal key factors ( 9 factors) and external key factors (4 factors). Internal key factors include: Innovation in production, licensing from MNCs, pharmaceutical industry and university cooperation, raw material production, R\&D projects based on market needs, quality of pharmaceuticals, private sector weakness, technological and physical infrastructure, and also knowledge and human infrastructure. Factors considered as external factors include: Government policies, Iran's political position in the world, lack of private sector investment, and intellectual property right. Finally, we asked managers about their point of view on 3 possible solutions for Iran's pharmaceutical development. These include supportive regulations, improving R\&D sector, and Joint venture with MNCs.

The sample of this study was based on the Tamin Pharmaceutical Investment Company (TPICO) managers' perspectives. TPICO is the largest pharmaceutical holding throughout the country and one of the largest pharmaceutical groups in the region. It is responsible for the management of 30 pharmaceutical companies belonging to The Social Security Investment Company, with a workforce of around 8000 personnel. It has a market share of over $70 \%$ of API, $30 \%$ of finished pharmaceuticals, and $40 \%$ distribution of the Iranian pharmaceutical market [22]. The opinions of TPICO managers' were assessed, and the questionnaire was sent to 65 individuals and on return, only 51 managers answered to the questionnaire (response rate was $78 \%$ )

\section{RESULTS}

Section 1: In this section, the state of internal key factors was assessed. The result of this part is presented in Table 2.

As seen in Table 2, most managers believe innovation in pharmaceuticals, licensing from MNCs, and raw material production have decreased during the past decades $(41 \%, 35 \%, 76 \%$, respectively), and some internal key factors were not in a good manner in the past; private sector and technological and physical infrastructure have weakened (29\% and 45\%, respectively), and R\&D projects have not been based on market needs (36\%). On the contrary, some factors have increased and improved; cooperation between pharmaceutical industry and university and the quality of pharmaceuticals have increased $(47 \%$ and $41 \%$, respectively), and knowledge and human infrastructure has improved (29\%) (Fig. 1).

Section 2: In this section, we assess managers' perspective about the effects of external factors on the pharmaceutical industry. The results are presented in Table 3

According to the results of Table 3, pharmaceutical managers indicated government policies have great effects on pharmaceutical industry's development, followed by Iran's political position in the world, the state of private sector investment, and intellectual property right respectively. Because of low response rate for intellectual property rights, answers for this one are not reliable.

Section 3: In this section, we asked managers' opinions about some solutions for Iran's pharmaceutical development. The results are presented in Table 4.

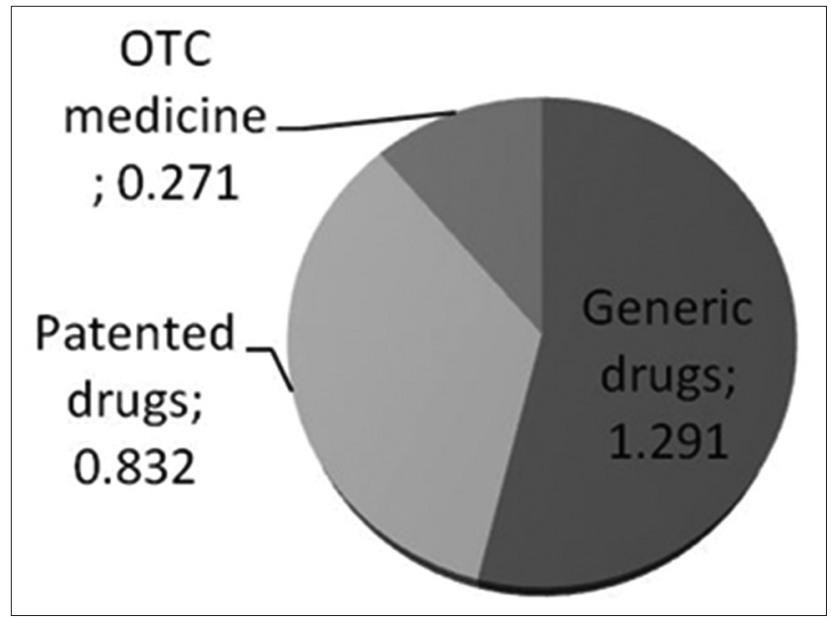

Fig. 1: Iran pharmaceutical market by subsector (US \$ bn), 2012 [16]

Table 1: Iran pharmaceutical market trend [19]

\begin{tabular}{|c|c|c|c|c|c|c|c|}
\hline Item & 1978 & 1981 & 1989 & 1997 & 2005 & 2008 & 2010 \\
\hline Pharmaceutical market value (million USD) & 1050 & 660 & 680 & 950 & 1450 & 2350 & 3255 \\
\hline Locally produced (value in percent) & 25 & 44 & 89 & 84 & 72 & 67 & 57 \\
\hline Pharmaceutical market volume (million number) & 6.8 & 5.9 & 11.3 & 15.8 & 26.5 & 31.3 & 32.1 \\
\hline Locally produced (volume in percent) & 31 & 48 & 95 & 96 & 96 & 97 & 91 \\
\hline Per capita pharmaceutical use (value, \$) & 30.0 & 16.5 & 12.8 & 15.3 & 21.0 & 33.1 & 43.9 \\
\hline Per capita pharmaceutical use (volume, item) & 194 & 148 & 213 & 255 & 384 & 441 & 434 \\
\hline
\end{tabular}


Table 2: The status of pharmaceutical industry's internal key factors; manger's perspective

\begin{tabular}{|c|c|c|c|c|c|c|c|}
\hline \multirow[t]{2}{*}{ Internal affecting factors } & \multicolumn{7}{|c|}{ Degree of increase } \\
\hline & Very high & High & Moderate & Low & Very low & Missing value & Total \\
\hline $\begin{array}{l}\text { Innovation in production } \\
\text { Counts } \\
\mathrm{n}(\%)\end{array}$ & $6(12)$ & $3(6)$ & $9(18)$ & $9(18)$ & $12(23)$ & $12(23)$ & $51(100)$ \\
\hline $\begin{array}{l}\text { Licensing from MNCs } \\
\text { Counts } \\
\mathrm{n}(\%)\end{array}$ & $6(12)$ & - & $3(6)$ & $15(29)$ & $24(47)$ & $3(6)$ & $51(100)$ \\
\hline $\begin{array}{l}\text { Pharmaceutical industry and university } \\
\text { cooperation } \\
\text { Counts } \\
\mathrm{n}(\%)\end{array}$ & $15(29)$ & $9(18)$ & $9(18)$ & $15(29)$ & - & $3(6)$ & $51(100)$ \\
\hline $\begin{array}{l}\text { Raw material production } \\
\text { Counts } \\
\mathrm{n}(\%)\end{array}$ & - & $12(23)$ & $18(36)$ & $6(12)$ & $12(23)$ & $3(6)$ & $51(100)$ \\
\hline $\begin{array}{l}\text { R\&D projects based on market needs } \\
\text { Counts } \\
\mathrm{n}(\%)\end{array}$ & $3(6)$ & $12(22)$ & $15(30)$ & $15(30)$ & $3(6)$ & $3(6)$ & $51(100)$ \\
\hline $\begin{array}{l}\text { Quality of pharmaceuticals } \\
\text { Counts } \\
\text { n(\%) }\end{array}$ & $6(12)$ & $15(29)$ & $18(35)$ & $9(18)$ & - & $3(6)$ & $51(100)$ \\
\hline $\begin{array}{l}\text { Private sector weakness } \\
\text { Counts } \\
\mathrm{n}(\%)\end{array}$ & $3(6)$ & $12(23)$ & $24(47)$ & $9(18)$ & - & $3(6)$ & $51(100)$ \\
\hline $\begin{array}{l}\text { Knowledge and human infrastructure } \\
\text { Counts } \\
\mathrm{n}(\%)\end{array}$ & $3(6)$ & $12(23)$ & $24(47)$ & $9(18)$ & - & $3(6)$ & $51(100)$ \\
\hline $\begin{array}{l}\text { Technological and physical infrastructure } \\
\text { Counts } \\
\text { n (\%) }\end{array}$ & - & $6(12)$ & $18(35)$ & $18(35)$ & $3(6)$ & $6(12)$ & $51(100)$ \\
\hline
\end{tabular}

R\&D: Research and Development, MNCs: Multinational companies

Table 3: The status of external factors' effects on pharmaceutical industry's development; mangers' perspective

\begin{tabular}{|c|c|c|c|c|}
\hline External effects & $\begin{array}{l}\text { Government } \\
\text { policies }\end{array}$ & $\begin{array}{l}\text { Iran's political position } \\
\text { in the world }\end{array}$ & $\begin{array}{l}\text { The state of private } \\
\text { sector investment }\end{array}$ & $\begin{array}{l}\text { Intellectual } \\
\text { property right }\end{array}$ \\
\hline $\begin{array}{l}\text { Degree of } \\
\text { significance }\end{array}$ & $\begin{array}{l}\text { Counts } \\
\text { n (\%) }\end{array}$ & $\begin{array}{l}\text { Counts } \\
\text { n (\%) }\end{array}$ & $\begin{array}{l}\text { Counts } \\
\text { n (\%) }\end{array}$ & $\begin{array}{l}\text { Counts } \\
\text { n (\%) }\end{array}$ \\
\hline Very high & $12(23)$ & $6(12)$ & - & - \\
\hline High & $18(35)$ & $9(18)$ & $18(35)$ & $6(12)$ \\
\hline Moderate & $12(24)$ & $27(52)$ & $18(35)$ & $24(47)$ \\
\hline Very low & $3(6)$ & $3(6)$ & - & - \\
\hline Missing value & $3(6)$ & $3(6)$ & $9(18)$ & $18(35)$ \\
\hline Total & $51(100)$ & $51(100)$ & $51(100)$ & $51(100)$ \\
\hline
\end{tabular}

Table 4: Policy implication for improving pharmaceutical industry capability; managers' perspective

\begin{tabular}{|c|c|c|c|}
\hline Policy implications & $\begin{array}{l}\text { Supportive } \\
\text { regulations }\end{array}$ & $\begin{array}{l}\text { Improving } \\
\text { R\&D sector }\end{array}$ & $\begin{array}{l}\text { Joint } \\
\text { venture }\end{array}$ \\
\hline $\begin{array}{l}\text { Degree of } \\
\text { significance }\end{array}$ & $\begin{array}{l}\text { Counts } \\
\text { n }(\%)\end{array}$ & $\begin{array}{l}\text { Counts } \\
\text { n (\%) }\end{array}$ & $\begin{array}{l}\text { Counts } \\
\text { n (\%) }\end{array}$ \\
\hline Very high & $24(47)$ & $6(12)$ & $36(70)$ \\
\hline High & $15(29)$ & $18(35)$ & $12(24)$ \\
\hline Moderate & $6(12)$ & $21(41)$ & - \\
\hline Low & $3(6)$ & $3(6)$ & - \\
\hline Very low & - & - & - \\
\hline Missing value & $3(6)$ & $3(6)$ & $3(6)$ \\
\hline Total & $51(100)$ & $51(100)$ & $51(100)$ \\
\hline
\end{tabular}

R\&D: Research and Development

As seen in Table 4, pharmaceutical managers believe supporting regulations, improving $\mathrm{R} \& \mathrm{D}$, and joint venture have a great impact on improving pharmaceutical industry $(76 \%, 47 \%$, and 94\%, respectively).

\section{DISCUSSION}

Most of the participants indicate that innovation has decreased in the pharmaceutical industry during last decades. That's why, the main goal of the generic scheme was accessibility to essential medicines ignored by industry's development and the newest drugs were imported. While the success of pharmaceutical innovation is affected by some factors such as, cooperation with universities, government policies, financial institute's supports, skilled labor force, and industry cooperation [23-25], Iranian pharmaceutical companies are poor in their physical infrastructure and are moderately growing in aspects of human resources and good manufacturing practices standards [26].

Most managers believe licensing has decreased during the past years $(76 \%)$. This is because their policies emphasize on domestic production, whereas licensing is less considered [27]. From the respondents' point of view, cooperation between pharmaceutical industries and universities has increased (47\%). While universities provide access to prominent scientists $[28,29]$, more requirements for formulation in pharmaceutical industry cause more needs in scientific 
labor. Furthermore, the trend of published papers in this field has been ascending within recent years [30]. Since development of the generic scheme, importation of finished products has decreased, and it has not had a considerable effect on the importation of raw materials (35\%). Subsidies that government allocated to manufacturers for buying raw materials have caused a reduction in innovation [11].

TPICO managers believe that R\&D projects have not been based on market needs (36\%) while accessibility to essential medicines is the prior policy for the pharmaceutical industry [11]. In addition, while the market is not competitive, no interest remains for R\&D investment. R\&D, which is spent in leading pharmaceutical industries, is about $16 \%$ of the company's sale [25,31], whereas pharmaceutical R\&D investment in Iran is very low and no investment is done in research [27]. In addition, human resources for R\&D account for only $1 \%$ of the whole pharmaceutical company's workforce in Iran [32] and pharmaceutical industry's technological capabilities are mainly limited to the areas of the formulation [11]

While lack of competition, delivers fewer motives for improving the quality of pharmaceuticals, managers indicated that quality of pharmaceuticals has increased over the past years (41\%). Based on the managers' point of view, the generic scheme has weakened the private sector in pharmaceutical sector (29\%). Supporting domestic pharmaceutical production via subsidy and categorization of companies, based on their products, leads to loss of competition in the domestic pharmaceutical market. In this unparalleled situation, there was no space for the activity of private companies. The generic scheme has increased manpower skills for making pharmaceuticals (29\%). The reason for this is clear, while the main goal of the generic scheme was formulation of medicines in the country, this required skilled labor force for formulation and more collaboration with pharmacy schools and scientific centers.

On top of this, they believed that the generic scheme had a negative impact on technological and physical infrastructure in this industry $(12 \%)$. It seems most of TPICO were manufacturing companies since before the Iranian revolution, and their technological infrastructure has not been upgraded to a great extent. Evidence shows establishing and developing pharmaceutical companies for producing raw materials, and generics has risen as about $70 \%$ of pharmaceutical companies in Iran were generated after the revolution [33]. Because the pharmaceutical industry is highly dependent on high-tech imported medicines, it encompasses much of their health-care budget and little remains for pharmaceutical reinvestment [11]. In recent years, some companies started to produce high-tech biological pharmaceuticals such as interferons, growth hormone, and erythropoietin [33]. Yet, Iran's technological capacity in pharmaceuticals is limited to formulation of medicines [11].

Generic drugs are more popular compared with branded ones, as evidence shows the generic market is expanding [34,35]. Generic drugs are cheaper for two reasons: First, the different pricing structures of generic drug manufacturers; More than $16 \%$ of brand drug prices are included for R\&D cost. As generic drugs do not have R\&D expenditures compared to new drugs, manufacturers are able to retain quality and provide drugs that are more affordable for patients. Second, legal limitations for generic drugs are far less than innovated drugs. For generic drugs, there are no complicated assessments for penetrating into the market, and often, bioavailability tests are sufficient [36]. The importance of the generic market will become more valuable with patent expiry of innovated drugs [35]. Furthermore, rapid growth of emerging markets that spend a lot on generic drugs will generally increase the generic market's portion [37].

Because the generic scheme has dominated Iran's pharmaceutical industry [11,15], internal factors inevitably became affected by it. Although conducting a whole generic based system had some benefits [11] for Iran's pharmaceutical sector, it affects Iran's pharmaceutical industry's development negatively via its effects on key internal factors. Due to the lack of right policies for branded generics formulations, there were no efficient ways for developing pharmaceutical industry and enhancing pharmaceutical exports. Some countries such as India, Turkey, Jordan, and China ascended their value chain by making large investments in the pharmaceutical industry and have become major producers not only for generic products but also for biopharmaceuticals [38]. While the general direction of policies was on drug availability and drug affordability, the generic scheme has resulted in improving accessibility in domestic market [15]. However, evidence shows domestic production and affordability of pharmaceuticals were not successful, as shown in Table 1, there is a growing trend of pharmaceutical imports in value term $[16,19]$. The main focus of generic scheme was saving and reducing costs of pharmaceutical; based on a study, that was done by budget and plan organization in 1989, "without generic scheme, we had to import US\$13 billion annually, while the imported pharmaceuticals were not more than $\$ 0 / 5$ billion annually during past years" [39]. Unfortunately, generic scheme ignored the development of pharmaceutical industry. To support domestic production, technological capability of the pharmaceutical industry has improved, but this improvement stopped at formulation level. In fact, emphasis on policies like essential medicine provision with affordable price and currency saving in pharmaceutical industry diminished market competitiveness. In addition, effects of the generic scheme on the quality of pharmaceuticals are controversial [11].

Government policies had great effects on pharmaceutical development via pharmaceutical tariff, no incentives for pharmaceutical exports, and lack of marketing standards. However, most of these policies have a negative effect on the development of Iran's pharmaceutical industry. Political position is an important factor that affects pharmaceutical development from TPICO managers' perspective. In fact, they believe unfavorable political situation has had adverse effects on the development of pharmaceutical policies (35\%).

Lack of private sector investment decreased the development of pharmaceutical sector (35\%), however, the first step toward privatization in all industries started from the development plan for the first 5 years in 1984 followed subsequently by other plans. Some national organizations such as National Welfare Organization, National Retirement Organization, charity foundations, and national banks purchased most parts of the pharmaceutical industry's stocks. NSSO alone owns more than $45 \%$ of the market share. In recent years, the private sector has had a remarkable growth in Iran's pharmaceutical industry, although this does not make up a large portion of the pharmaceutical market. Iran like other Middle Eastern countries is moving toward intellectual property protection (IPR) [17] and has set laws for patents and IPR since 1925. However, there is no law for protecting innovations. Licensing for pharmaceuticals is done by $\mathrm{MOH}$ in Iran. Trade mark must be registered, and the generic name must be published on the labeling along with the brand name. IPR is a controversial issue in pharm-emerging markets [40]. Iran's membership to World Trade Organization will have a drastic impact on the pharmaceutical market because the copy of patented medicines in the market will be restricted and it needs further resource allocation for novel and hi-tech medicines. TPICO managers greatly assessed the effect of IPR on Iran pharmaceutical industry. However, because most managers did not answer this question (35\% unanswered), the judgment about this factor is not precise.

For improving Iran's pharmaceutical industries, managers believed that supportive regulations are highly needed for improving the market (76\%). Their point of view about needs for improving R\&D was moderately high and very high about joint venture with MNCs, which is needed for pharmaceutical industry development (47\% and $94 \%$, respectively, for each one). 


\section{CONCLUSION}

To improve the pharmaceutical industry, a more competitive environment is required. $\mathrm{MOH}$ should adopt policies with producing branded generics that are expected to improve the quality of domestic pharmaceutical productions [27]. In fact, Iran's pharmaceutical industry has much more potential capabilities for future growth and development [27]. However, more investment is required in pharmaceutical infrastructures, revising pharmaceutical regulations regarding enhancing industry (entering to) in international markets, reinvesting in the private sector, and promoting national and international investment in the pharmaceutical industry. Furthermore, for improving the pharmaceutical industry in the shortest time possible, improvement of technological capabilities and investment in $\mathrm{R} \& \mathrm{D}$ should be considered.

\section{REFERENCES}

1. Moncada-Paternò-Castello P, Ciupagea $\mathrm{C}$, Smith K, Tübke A, Tubbs M Does Europe perform too little corporate R\&D? A comparison of EU and non-EU corporate R\&D performance. Res Policy 2010;39(4):523-36z.

2. Danzon PM, Towse A. Differential pricing for pharmaceuticals: reconciling access, $R \& D$ and patents. Int $J$ Health Care Finance Econ 2003;3(3):183-205.

3. Competitiveness of the EU Market and Industry for Pharmaceuticals European Commission: Welfare Implications of Regulation; 2011.

4. Blau G, Mehta B, Bose S, Pekny J, Sinclair G, Keunker K, et al. Risk management in the development of new products in highly regulated industries. Comput Chem Eng 2000;24(2):659-64.

5. Holmer AF. The pharmaceutical industry - to whom is it accountable? N Engl J Med 2000;343(19):1415.

6. Commission E. Communication from the Commission-Executive Summary of the Pharmaceutical Sector Inquiry Report. Reference EU Commission Report; 2009. p. 8.

7. Fischer MA, Avorn J. Economic consequences of underuse of generic drugs: evidence from Medicaid and implications for prescription drug benefit plans. Health Serv Res 2003;38(4):1051-63.

8. Hogerzeil HV, Mirza Z. The world Medicines Situation 2011: Access to Essential Medicines as Part of the Right to Health. Geneva: World Health Organization (WHO); 2011.

9. Basmanji K. Pharmaceuticals in Iran: An overview. History of Contemporary Medicine in Iran. Arch Iran Med 2004;7(2):158-64.

10. Mehralian G, Rasekh HR, Akhavan P, Sadeh MR. The Impact of intellectual capital efficiency on market value: An Empirical study from Iranian pharmaceutical companies. Iran J Pharm Res 2012;11(1):195-207.

11. Cheraghali AM. Iran pharmaceutical market. Iran J Pharml Res 2006;5(1):1-7.

12. Iran National Drug Policy (NDP) revision; 2004

13. Mehralian G, Gatari AR, Morakabati M, Vatanpour H. Developing a suitable model for supplier selection based on supply chain risks: An empirical study from Iranian pharmaceutical companies. Iran J Pharm Res 2012;11(1):209-19.

14. Iran Pharmaceutical \& Healthcare Report; 2004.

15. Davari M, Walley T, Haycox A. Pharmaceutical policy and market in Iran: Past experiences and future challenges. J Pharm Health Serv Res 2011;2(1):47-52.

16. Iran pharmaceutical \& Healthcare Report. Business Monitor
International; 2012.

17. Tantash M. Middle east generics, challenges and opportunity, journal of generic medicines. Journal of generic medicines. Bus J Generic Med Sect 2012;9(1):13-20.

18. Food \& Drug regulation. Food \& Drug Organisation; 2010.

19. Annual Report. Food \& Drug Report; 2012. Available from: http:// www.fdo.ir.. [Last cited on 2013 Nov 4].

20. Force PICT. Competitiveness and Performance Indicators. London: PICTF; 2005 .

21. Michels D, Jonnard A, Bretscher C, Summers J, Wanser S, Flynn J. Review of Global Competitiveness in the Pharmaceutical Industry. Washington, DC: US International Trade Commission Staff Research Study No.; 1999. p. 25.

22. Available from: http://www.tpico.ir. [Last cited on 2013 Nov 4].

23. Bagchi-Sen S. Strategic considerations for innovation and commercialization in the US biotechnology sector. Eur Plan Stud 2007;15(6):753-66.

24. Munos B. Lessons from 60 years of pharmaceutical innovation. Nat Rev Drug Discov 2009;8(12):959-68.

25. Kesič D. Strategic analysis of the world pharmaceutical industry. Manage J Contemp Manage Issues 2009;14(1):59-76.

26. A K. Drug Quality in Islamic Repulic of Iran. Office for Narcotics and Drug Supervision and Evaluation's Internal Report; 2001.

27. Rasekh HR, Mehralian G, Vatankhah-Mohammadabadi AA. Situation analysis of R \& d activities: an empirical study in Iranian pharmaceutical companies. Iran J Pharm Res 2012;11(4):1013-25.

28. Kenney M. Biotechnology and the Creation of a New Economic Space. Private Science: Biotechnology and the Rise of the Molecular Sciences. Philadelphia, PA: University of Pennsylvania Press; 1998. p. 131-43.

29. Mehralian G, Rajabzadeh A, Sadeh MR, Rasekh HR. Intellectual capital and corporate performance in Iranian pharmaceutical industry. J Intellect Cap 2012;13(1):138-58.

30. 2013. Available from: http://www.scimagojr.com/countrysearch php? country $=$ IR\&area $=0$. [Last cited on 2013 Dec 4].

31. Subramanian R, Toney JH, Jayachandran C. The evolution of research and development in the pharmaceutical industry: Toward the open innovation model-can pharma reinvent itself? Int J Bus Innov Res 2011;5(1):63-74.

32. Kebriaizade A, Abdollahiasl A. Take a look at Iran pharmaceutical industry in Iran. Iran J Pharm Res (IJPR);2003; ISSN 1735-031, 9.

33. Descriptive Progress Report. Ministry of Health, Organization FaD; 2005.

34. The Global use of Medicines Outlook Through 2016Report. IMS Institute; 2012.

35. Garattini L, Tediosi F. A comparative analysis of generics markets in five European countries. Health Policy 2000;51(3):149-62.

36. Bae JP. Drug patent expirations and the speed of generic entry. Health Serv Res 1997;32(1):87-101.

37. Pharmaceutical Executive, Strategies for Emerging Markets: Seven Keys to the Kingdom. IMS Health 2010 by Villiam Looney Pharmaceutical executive.

38. Attridge CJ, Preker AS. Improving Access to Medicines in Developing Countries: Application of New Institutional Economics to the Analysis of Manufacturing and Distribution Issues World Bank. Washangton, DC: The World Bank; 2005.

39. Iranian Parliament. National Health Insurance Act. J Med Serv Insur Organ 1994;7:68-71.

40. Mehralian G, Rasekh HR, Akhavan P, Ghatari AR. Prioritization of intellectual capital indicators in knowledge-based industries: Evidence from pharmaceutical industry. Int J Inf Manage 2013;33(1):209-16. 